\title{
FOUR NEW SPECIES OF MONHYSTERIDS (NEMATODA: MONHYSTERIDA) FROM MANGROVES OF THE MEKONG RIVER ESTUARIES OF VIETNAM
}

\author{
VLADIMIR G. GAGARIN \\ Institute of Inland Waters Biology, Russian Academy of Sciences, Russia \\ NGUYEN VU THANH \\ Institute of Ecology and Biological Resources, Vietnam
}

\begin{abstract}
Four new free-living nematode species of the order Monhysterida from Me Kong River estuaries of Vietnam are described. Thalassomonhystera tenuis sp. nov. resembles to Thalassomonhystera pusilla (Boucher, Heleouët, 1977) but differs from it by the high, isolated labial region, longer outer labial setae, shorter oesophagus, shorter spicules, absence of gubernaculum's dorso-caudal apophysis and presence of subterminal setae on the tip. Diplolaimelloides elegans sp. nov. resembles to Diplolaimelloides meyli Timm, 1961, but it differs in having longer and slender tail and vulva position located in more anterior body end. Sphaerotheristus supplementatus sp. nov. comes close to Sphaerotheristus parvus Gagarin, Nguyen Vu Thanh, 2006, it differs in having the longer and thinner body and papillae-shaped supplements in males. Terschellingia obesa sp. nov. similar to Terschellingia monohystera Wieser, Hopper 1967 and Terschellingia brevicaudata Ott, 1972, but it differs from $T$. monhystera in having shorter cephalic setae, others vulva position and absence of oesophagus basal bulb; it also differs from T. brevicaudata in having shorter body, shorter cephalic setae, shorter spicules and presence of one ovary.
\end{abstract}

Key words: Free-living nematodes, new species, Me Kong river estuary, mangrove, Vietnam.

Fauna of free-living brackish water and marine nematodes of Vietnam is studied recently. At present, the investigating nematode biodiversity is strongly improved, in connection with creating of the new database for the bio-monitoring assessment of water quality in watershed and wetland ecosystems of Vietnam. This work was focused on biodiversity study of free-living aquatic nematode fauna of the mangrove forests of Vietnam during 2000-2008 years. The nematode samples were collected at the November 2006. In this paper, four new species, Thalassomonhystera tenuis sp. nov., Diplolaimelloides elegans sp. nov., Sphaerotheristus supplementatus sp. nov., Terschellingia obesa sp. nov. are described.

\section{MATERIAL AND METHODS}

Samples were collected by a Ponar grab. In each station one grab was done with three replicated for nematodes analysis. All samples were fixed in hot formalin $10 \%$. The nematodes were extracted by LUDOX-TM 50 solution with centrifugation method and gradually transferred to anhydrous glycerin and finally mounted into permanent slides.

Abbreviation used in the text: $L$. total body length $(\mu \mathrm{m})$; a. body length divided by maximum body width; $b$. body length divided by esophageal length; c. body length divided by tail length; c'. tail length measured anal or cloacal body diameter; V. relation of distance from anterior body end to vulva for body length at percent.

\section{DESCRIPTION}

1. Family Monhysteridae de Man, 1876

Thalassomonhystera tenuis sp. nov. (fig. 1)

Measurements: table 1. 


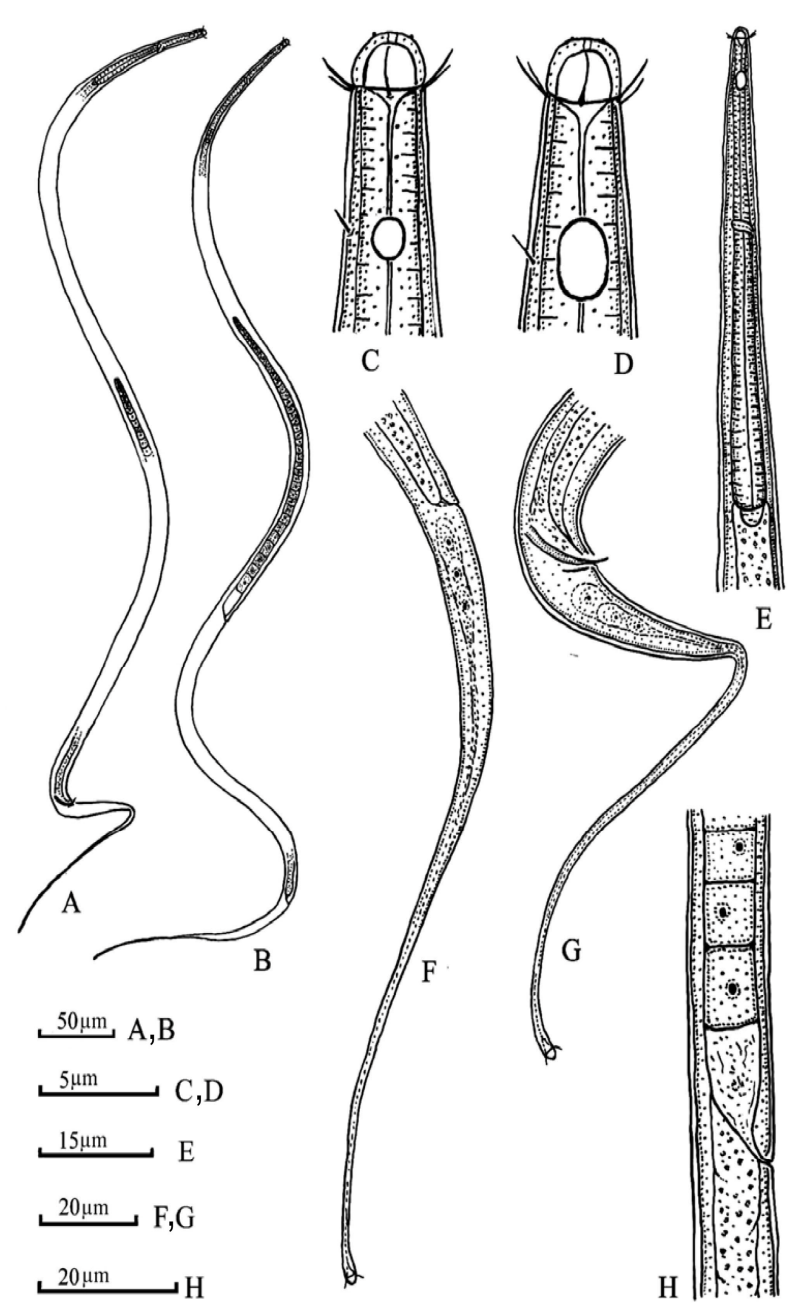

Figure 1. Thalassomonhystera tenuis sp. nov.

A. Entire male; D. Head region; E. Anterior end of body; G. Posterior end of body and tail; B. Entire female; C. Head region; F. Tail; H. Vulva region.

Female: Body small and thin. Cuticle smooth, 0.6-0.8 $\mu \mathrm{m}$ thick. Lateral fields and somatic setae absent. Labial region isolated from body contour by the redrawing rest. Inner labial sensillae in shape of obscure papillae. Six outer labial and four cephalic setae united in almost one circle. Outer labial setae longer cephalic setae about $60-70 \%$ of labial region width. Amphidial fovea circular, about $3 \mu \mathrm{m}$ in diameter. Anterior margin of amphidial fovea situated 6.5-8.0 $\mu \mathrm{m}$ (2.3-2.7 labial region width) from anterior body end. Cervical setae present. Cheilostoma spacious, with sclerotized walls. Esophastoma small funnel-shaped, its walls slightly sclerotized. Oesophagus slender, cylindroid, slightly widened at the posterior end. Cardia cordate, surrounded with intestinal tissue. Ventral gland, its canal and excretory pore not observed. Rectum length shorter than anal body diameter.

Female gonad single, anterior, outstretched, situated entirely to the right of the intestine. Vagina comparatively short, bent to anterior body end. Uterus spacious, contain numerous small rounded spermatozoa. No postvulval sac. Vulva posterior to mid-body, crescent-shaped; its lips not cuticularized and not protruded. Tail slender, with proximal conical and distal cylindrical portions gradually going over into 
one another. Tail tip with two subterminal setae. Caudal glands and spinneret present.

Male: similar to females in general morphology. Cuticle smooth, thin. Lateral fields and somatic setae absent. Labial region isolated from body contour by the redrawing rest. Inner labial sensillae in shape of minute papillae; outer labial and cephalic sensillae in shape of thin setae. Amphidial fovea in shape of stretched in longitudinal direction ellipse, 4.0$4.5 \mu \mathrm{m}$ long. Structure of buccal cavity and oesophagus similar to structure of female.

Male gonad single, outstretched, situated to the right of the intestine. Spicules short, arcuate, distally pointed and proximally widened, without knobs. Gubernaculum in shape of thin plate, without dorso-caudal apophysis. Precloacal supplements absent. Tail tip with two subterminal setae. Shape of tail as that of female. Caudal glands and spinneret present.

Type locality and habitat: Mekong River Estuary. Shore line, mangrove. Depth of waters $1.5-4.0 \mathrm{~m}$, fine silt, salinity $18-23 \hat{\mathrm{E}}$.

Type material: holotype male on slide number 23/III and paratypes $1 \hat{0}$ and 2 우 deposited at the nematode collection of the Institute of Inland Waters Biology, Borok, Russia. Paratypes $5 \hat{\partial} \widehat{\partial}$ and $1 q$ deposited at the nematode collection of the Institute of Ecology and Biological Resources, Vietnamese Academy of Science and Technology, Hanoi, Vietnam.

Differencial diagnosis: the new species can be easy distinguished from all known species of the genus Thalassomonhystera by the high labial region, isolated from the body contour by the redrawing rest. Nevertheless, Thalassomonhystera tenuis sp. nov. resembles to. Thalassomonhystera pusilla (Boucher et Hellouët 1977), but differs from it in having longer outer labial setae $(65-75 \%$ vs $50-55 \%)$, shorter oesophagus $(b=4.8-5.7$, vs $b=8.0$ 11.0), shorter spicules (17-20 $\mu \mathrm{m}$, vs 12-14 $\mu \mathrm{m})$, absence of dorso-caudal apophysis at gubernaculum and presence of subterminal setae at tail tip (Boucher et Helleouët, 1977).

Etymology: the species name means "thin".

Table 1

Measurements of Thalassomonhystera tenuis sp. nov. (all measurements in $\mu \mathrm{m}$, except ratio)

\begin{tabular}{|l|c|c|c|c|c|}
\hline \multirow{2}{*}{ Characteristics } & \multirow{2}{*}{ Holotype } & \multicolumn{5}{c|}{ Paratypes } \\
\cline { 3 - 6 } & & \multicolumn{2}{|c|}{6 ô } & \multicolumn{2}{c|}{3 우 } \\
\cline { 3 - 6 } & & range & mean & range & mean \\
\hline L & 668 & $599-771$ & 666 & $721-815$ & 782 \\
\hline a & 61 & $60-70$ & 63 & $62-66$ & 64 \\
\hline b & 8.0 & $7.4-11.0$ & 8.8 & $9.0-9.7$ & 9.3 \\
\hline c & 7.1 & $6.5-9.4$ & 7.5 & $5.3-5.6$ & 5.5 \\
\hline c' & 11.2 & $9.0-13.6$ & 11.1 & $17.5-18.4$ & 18.1 \\
\hline V, \% & --- & --- & --- & $52.8-54.9$ & 53.9 \\
\hline Labial region width & 3.0 & $3.0-3.5$ & 3.0 & 3.0 & 3.0 \\
\hline Outer labial setae length & 2.0 & $2.0-2.5$ & 2.0 & $2.0-2.5$ & 2.3 \\
\hline Anterior body end to amphids & 8.0 & $7.0-10.0$ & 8.5 & $7.0-9.0$ & 8.0 \\
\hline Oesophagus length & 84 & $69-84$ & 76 & $74-91$ & 84 \\
\hline Posterior end of oesophagus to vulva & --- & --- & --- & $322-350$ & 337 \\
\hline Posterior end of oesophagus to cloaca & 490 & $427-616$ & 499 & --- & --- \\
\hline Vulva to anus & --- & --- & --- & $196-231$ & 218 \\
\hline Tail length & 94 & $73-99$ & 91 & $129-154$ & 143 \\
\hline Spicules length (along arch) & 13 & $12-14$ & 13 & --- & --- \\
\hline
\end{tabular}


Diplolaimelloides elegans sp. nov. (fig. 2)

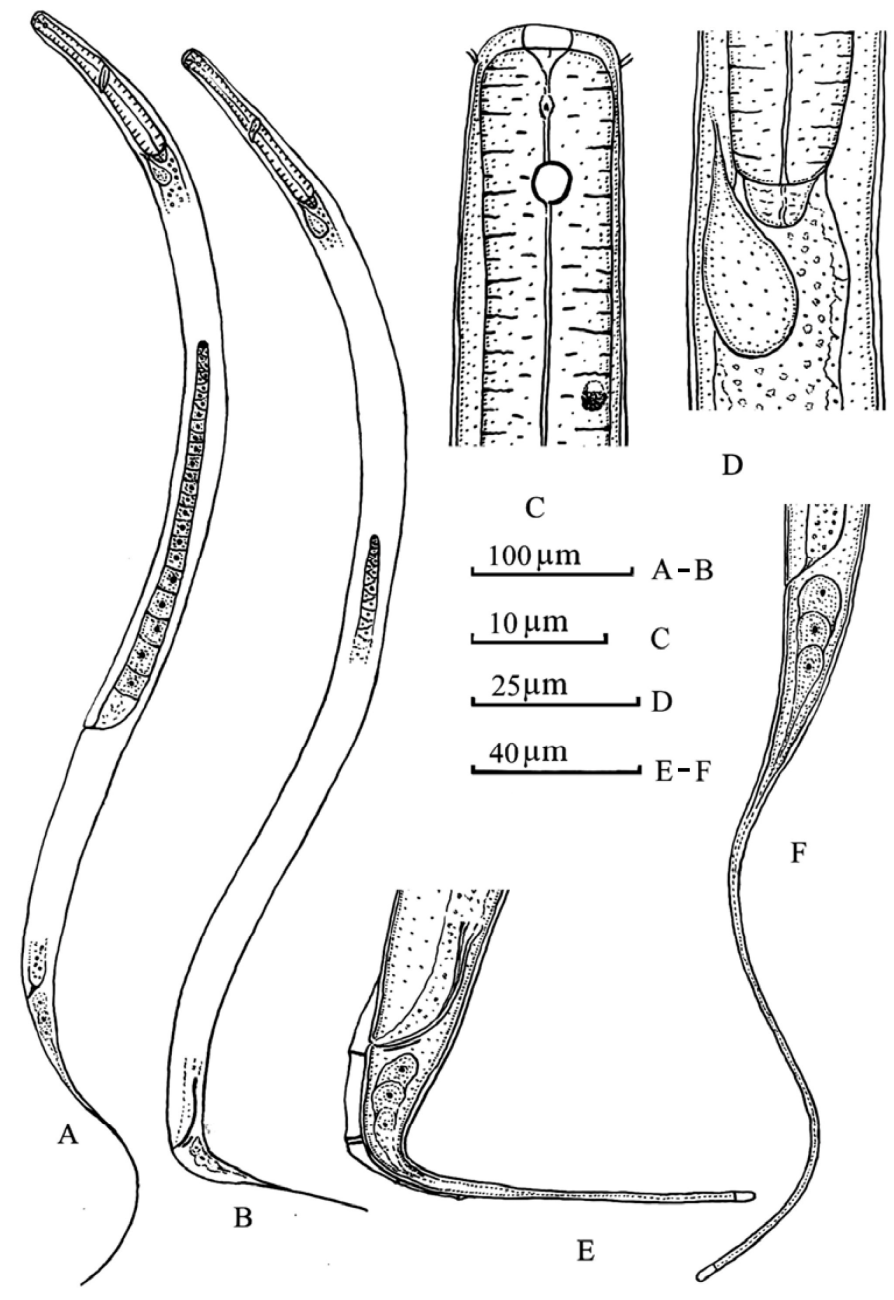

Figure 2. Diplolaimelloides elegans sp. nov.

A. Entire female; D. Cardia region; F. Tail; B. Entire male; C. Head region; E. Tail.

\section{Measurements: table 2 .}

Female: body slender and comparatively small. Cuticle smooth, thin. Thickness of cuticle about $1.0 \mu \mathrm{m}$ in mid-body. Lateral fields, somatic and cervical setae absent. Lips not pronounced. Inner labial sensillae not visible. Six outer labial and four cephalic setae small and united in almost one circle. Cephalic setae about $1 \mu \mathrm{m}$ long (10-11\% of labial region width). Stoma in shape of shallow-funnel. Small tooth in the anterior part of oesophagus. Ocelli brown color, situated at distance $42-45 \mu \mathrm{m}$ from anterior body end (4.1-4.5 labial region width). Amphidial fovea in shape of broken circle, 2.5 $\mu \mathrm{m}$ in diameter. Oesophagus slender, muscular, slightly widened in the posterior end, but not form basal bulb. Cardia muscular, surrounded with intestinal tissue. Ventral gland baggyshaped, localized at ventral slide of body, at level of posterior oesophagus end. Rectum as long as anal body diameter or slightly shorter its.

Reproductive system monodelphic, prodelphic; ovary outstretched, situated to right of intestine. Oogonia arranged in one or two rows in germinal zone and single row of an enlarging oocytes arranged in growth zone. Vagina short, bended to anterior body end. Uterus spacious, filled with small rounded spermatozoa. Postvulval uterine sac absent. Vulva posterior to mid-body, crescent-shaped; 
its lips not cuticularized and not protruded. Tail slender, long, gradually narrowing to its proximal end. Caudal glands well developed. Spinneret in shape of narrow tube.

Male: similar to females in general morphology. Cuticle thin, smooth. Lateral fields, somatic and cervical setae absent. Lips not pronounced. Inner labial sensillae not visible. Outer labial and cephalic setae about 1 $\mu \mathrm{m}$ long and united in almost one circle. Amphidial fovea in shape of broken circle 3.0 $\mu \mathrm{m}$ in diameter ( $25 \%$ of the corresponding body diameter), its anterior margin situated at distance of $18 \mu \mathrm{m}$ from anterior body end. Structure of head and oesophagus to that of females.

Testis single, outstretched, situated to right of intestine. Spicules thin, bended, cephalated, 2.5 times as long as cloacal body diameter. Gubernaculum in shape of thin plate. Copulatory bursa present, with five pairs of papillae, moreover second and third pairs arranged near one to another. Tail slender, bended dorsally, with proximal conical and distal cylindrical portions gradually going over into one another. Caudal glands well developed. Spinneret in shape of narrow tube.

Type locality and habitat: Me Kong River Estuary. Shore line, mangrove forest. Depth of waters $2.0-4.0 \mathrm{~m}$, fine slit, salinity $18-23 \hat{\mathrm{E}}$.

Type material: holotype male on slide number 36/III and paratype one female deposited at the nematode collection of the Institute of Inland Waters Biology, Borok, Russia.

Paratype one female deposited at the nematode collection of the Institute of Ecology and Biological Resources, Vietnamese Academy of Science and Technology, Hanoi, Vietnam.

Differential diagnosis: the new species morphologically resembles to Diplolaimelloides meyli Timm, 1961, but differs from it in having the longer and slender tail (in D. meyli $c=9.4$ 17.7, $c \square=2.3-4.8$ vs $c=4.2-7.2$ and $c \square-6.1$ 11.7 in new species) and another localization of vulva (in D. meyli $\mathrm{V}=61.9-68.3 \%$ vs $\mathrm{V}=56.0$ $59.3 \%$ in new species.

Etymology: the species name means "graceful", "elegant".

Table 2

Measurements of Diplolaimelloides elegans sp. nov.

(all measurements in $\mu \mathrm{m}$, except ratio)

\begin{tabular}{|l|c|c|}
\hline \multicolumn{1}{|c|}{ Characteristics } & Holotype Oे $^{\boldsymbol{1}}$ & Paratypes, 2 + + \\
\hline $\mathrm{L}$ & 835 & 809,826 \\
\hline $\mathrm{a}$ & 35 & 28,30 \\
\hline $\mathrm{b}$ & 7.2 & $7.0,7.4$ \\
\hline $\mathrm{c}$ & 7.2 & $5.3,4.2$ \\
\hline c' & 6.1 & $10.0,11.7$ \\
\hline $\mathrm{V}$ & --- & $59.3,56.0$ \\
\hline Labial region width & 11 & 10,11 \\
\hline Outer labial setae length & 1.0 & 1.0 \\
\hline Anterior body end to amphids & 18 & 18,17 \\
\hline Anterior body end to ocelli & 45 & 45,42 \\
\hline Oesophagus length & 116 & 115,112 \\
\hline Posterior end of oesophagus to vulva & --- & 365,350 \\
\hline Posterior end of oesophagus to cloaca & 603 & --- \\
\hline Vulva to anus & --- & 175,168 \\
\hline Tail length & 116 & 154,196 \\
\hline Spicules length (along arch) & 46 & --- \\
\hline Gubernaculus length & 14 & --- \\
\hline
\end{tabular}




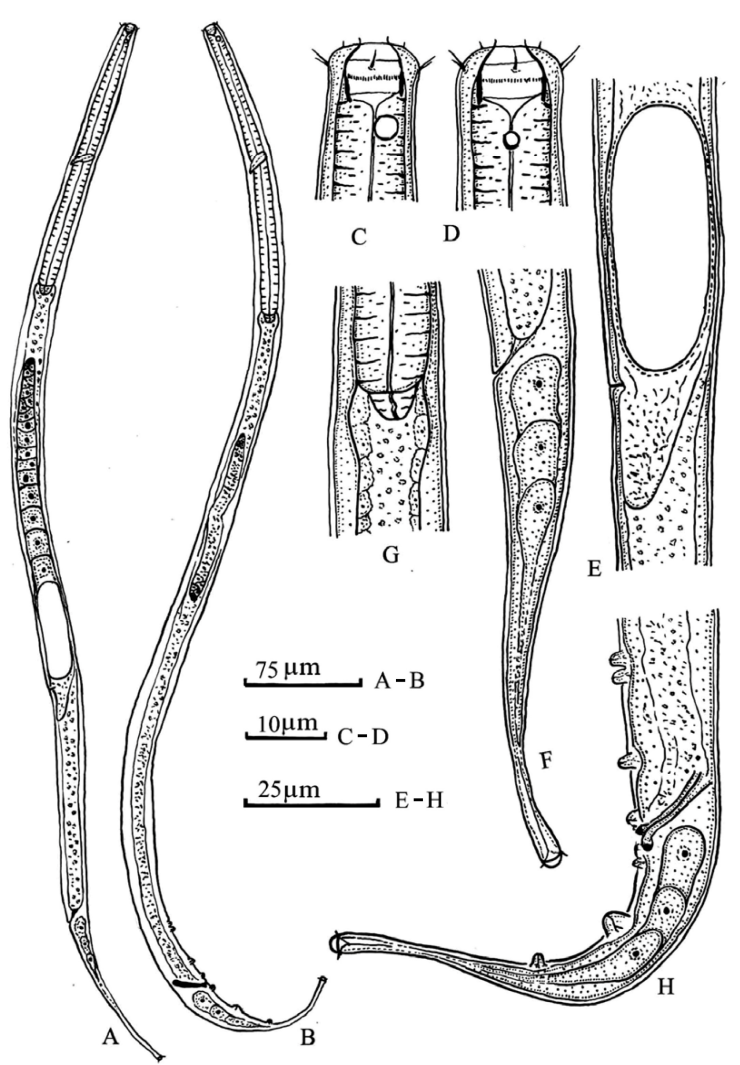

Figure 3. Sphaerotheristus supplementatus sp. nov.

A. Entire female; D. Head region; E. Vulva region; F. Tail;

G. Cardia region; B. Entire male; C. Head region; H. Tail.

\section{Family Xyalidae Chtwood, 1951}

\section{Sphaerotheristus supplementatus sp. nov.} (fig. 3)

Measurements: table 3.

Female: Body slender and small. Cuticle delicate annulated. Thickness of cuticle about $1.0 \mu \mathrm{m}$ in mid-body. Lateral fields, somatic and cervical setae absent. Lips not pronounced. There are very minute inner labial setae. Six outer labial and four cephalic setae united in almost one circle. Outer labial setae slightly longer than cephalic setae and $20-30 \%$ of labial region width. Buccal cavity in shape of short cylinder measuring 6.0-7.5 $\times$ 6.0-7.0 $\mu \mathrm{m}$. Cheilostoma spacious, its walls poorly cuticularized. Esophastoma walls strongly cuticulized and gymnostoma clearly isolated from stegostoma. Amphidial fovea circular, 2.0$2.5 \mu \mathrm{m}$ in diameter $(17-21 \%$ of corresponding body width), its anterior margin situated 8.0-
$10.0 \mu \mathrm{m}$ from anterior body end. Oesophagus slender, muscular, slightly widened at the posterior end, but not form basal bulb. Cardia muscular, surrounded with intestinal tissue. Ventral gland, its canal and excretory pore not visible. Rectum 0.6-0.8 times as long as anal body diameter.

Reproductive system monodelphic, prodelphic; ovary straight, situated to left side of intestine. Oogonia arranged in one or two rows and single row of gradually enlarging oocytes in growth zone. Vagina straight, short. Uterus spacious, filled with small rounded spermatozoa and containing one egg, measuring 47-66 $\times 18$ $24 \mu \mathrm{m}$. Postvulval uterine sac present, $18-32 \mu \mathrm{m}$ long. Vulva posterior to mid-body, crescent-shaped; its lips not cuticularized and not protruded. Tail slender, with proximal conical and distal cylindrical portions gradually going over into one another. Papillae and setae at tail absent. Terminus of tail slightly swollen, 
with two short subterminal setae. Three caudal glands terminating in one chamber and opening through spinneret.

Male: similar to females in general morphology. Cuticle delicate annulated. Lateral fields, somatic and cervical setae absent. Lips not pronounced. Inner labial setae very minute. Six outer labial and four cephalic setae united in almost one circle. Outer labial setae slightly longer than cephalic setae. Amphidial fovea circular $2.5-3.5 \mu \mathrm{m}$ in diameter $20-25 \%$ of the corresponding body diameter), its anterior margin situated 7.0-9.0 $\mu \mathrm{m}$ from anterior body end. Structure of buccal cavity and oesophagus similar to that of female.

Testes two, opposite; anterior testis outstretched to left intestine, posterior testis reflexed to right of intestine. Spicules straight, slender, non-cephalated, 1.1-1.3 times as long as cloacal body diameter. Apical spicules end slightly curved, thick and with turn at outer side. Gubernaculum absent. Four supplements in shape of papillae situated in front of cloaca. Two precloacal papillae supplements closely with each others arranged far from cloaca. Three similar papillae arranged in tail. Tail slender, with proximal conical and distal cylindrical portions gradually going over into one another. Tail terminus slightly swollen, with two short subterminal setae. Three caudal glands and spinneret well developed.

Type locality and habitat: Mekong River Estuary. Shore line, mangrove. Depth of waters

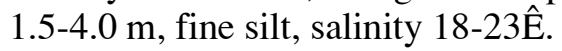

Type material: holotype male on slide number 22/III and paratypes $2 \widehat{\delta} \widehat{\delta}$ and 2 우 deposited at the nematode collection of the Institute of Inland Waters Biology, Borok, Russia.

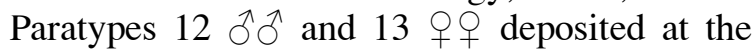
nematode collection of the Institute of Ecology and Biological Resources, Vietnamese Academy of Science and Technology, Hanoi, Vietnam.

Differential diagnosis: the new species morphologically resembles to Sphaerotheristus parvus Gagarin, Nguyen Vu Thanh, 2006 but it differs from Sph. parvus in having the longer and thinner body (in Sph. parvus $\mathrm{L}=405-468$ $\mu \mathrm{m}, \mathrm{a}=22-23$ vs $\mathrm{L}=525-736 \mu \mathrm{m}, \mathrm{a}=32-43$ in new species) and presence of papillae-shaped supplements in males (Gagarin, Nguyen $\mathrm{Vu}$ Thanh, 2006).

Etymology: the species name means "with supplements".

Table 3

Measurements of Sphaerotheristus supplementatus sp. nov. (all measurements in $\mu \mathrm{m}$, except ratio)

\begin{tabular}{|c|c|c|c|c|c|}
\hline \multirow{3}{*}{ Characteristics } & \multirow{3}{*}{ Holotype } & \multicolumn{4}{|c|}{ Paratypes } \\
\hline & & \multicolumn{2}{|c|}{$15 \hat{O} 0^{\lambda}$} & \multicolumn{2}{|c|}{$15 ㅇ ㅗ$} \\
\hline & & range & mean & range & mean \\
\hline $\mathrm{L}$ & 589 & $525-665$ & 599 & $629-736$ & 671 \\
\hline a & 35 & $32-43$ & 38 & $29-37$ & 32 \\
\hline $\mathrm{b}$ & 3.5 & $3.4-4.3$ & 3.8 & $3.5-4.4$ & 3.9 \\
\hline $\mathrm{c}$ & 8.0 & $6.9-9.0$ & 8.0 & $5.7-6.9$ & 6.2 \\
\hline$c^{\prime}$ & 5.3 & $4.3-6.0$ & 5.1 & $6.2-8.8$ & 7.1 \\
\hline $\mathrm{V}, \%$ & --- & --- & --- & 61.4-66.7 & 63.8 \\
\hline Labial region width & 10 & $10-11$ & 10 & $10-11$ & 11 \\
\hline Outer labial setae length & 2.5 & $2.5-3.0$ & 2.5 & $2.0-3.0$ & 2.5 \\
\hline Anterior body end to amphids & 8.5 & 7.0-.9.0 & 8.0 & $8.0-10.0$ & 9.0 \\
\hline Oesophagus length & 168 & $150-174$ & 160 & $160-182$ & 172 \\
\hline Posterior end of oesophagus to vulva & --- & --- & --- & 234-287 & 256 \\
\hline Posterior end of oesophagus to cloaca & 347 & $308-435$ & 364 & --- & --- \\
\hline Vulva to anus & --- & --- & --- & $118-155$ & 134 \\
\hline Tail length & 74 & $67-84$ & 75 & $96-120$ & 109 \\
\hline Spicules length (along arch) & 17 & $16-18$ & 17 & --- & --- \\
\hline
\end{tabular}




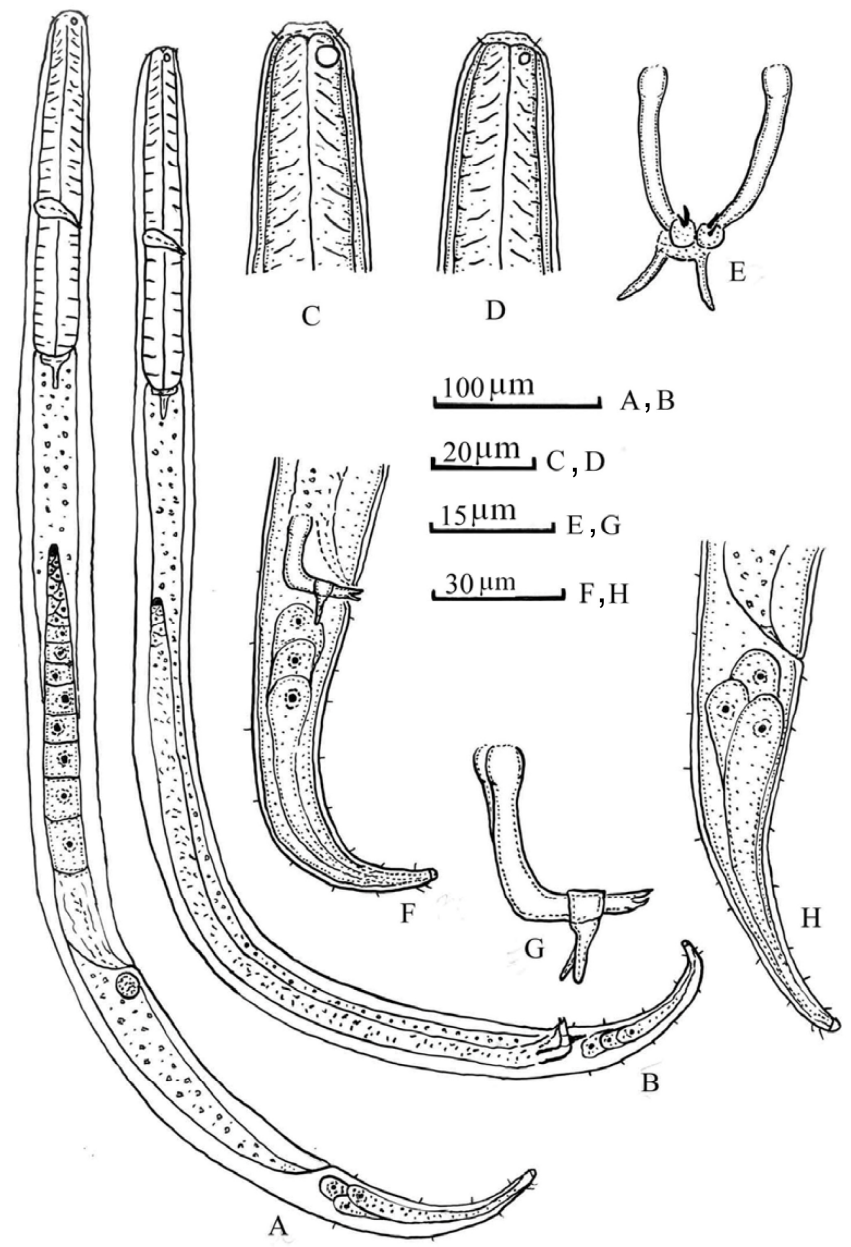

Figure 4. Terschellingia obesa sp. nov.

A. Entire female; D. Head region; H. Tail. B. Entire male; C. Head male; E, G. Spicule apparatus; F. Tail.

\section{Family Linhomoeidae Filipjev, 1922}

Terschellingia obesa sp. nov. (fig. 4)

Measurements: table 4.

Female: Body small, comparatively thick nematode. Cuticle finely annulated. Thickness of cuticle 0.7-1.0 $\mu \mathrm{m}$. Somatic setae rare, short. Anterior body end narrowed. Lips not pronounced. Labial region 0.3-0.4 times as wide as body diameter at region of posterior oesophagus end. Labial sensillae not visible. Four cephalic setae about $1.5 \mu \mathrm{m}$ long $(8-10 \%$ of labial region width). Cervical setae absent. Stoma not developed. Amphidial fovea in shape of circle $3.0-3.5 \mu \mathrm{m}$ in diameter and situated at distance of 3-5 $\mu \mathrm{m}$ from anterior body end.
Oesophagus muscular. Slanting muscles well developed in its anterior portion. Oesophagus widened in its base, but not formed bulb. Cardia long, muscular, surrounded with intestinal tissue. Ventral gland, its channel and excretory pore not visible. Rectum as long as anal body diameter or slightly longer it.

Female gonad single, anterior, outstretched, situated entirely to the right of the intestine. Vulva post-equatorial, in shape of transverse split. Vulva lips not cuticularized and not protruded. Vagina short, bended to anterior body end. Postvulval uterine sac absent. There is one postvulval gland cell with granular content. Tail slender, elongate-conical, bended ventrally, armed short setae. Caudal glands and spinneret well developed. 
Male: similar to females in general morphology. Cuticle finely annulated. Somatic setae rare and short. Head armed with 4 short setae. Stoma not developed. Amphidial fovea in shape of circle 4.5-5.0 $\mu \mathrm{m}$ in diameter and situated at distance of 3-6 $\mu \mathrm{m}$ from anterior body end. Oesophagus muscular, widened in its base, but not formed bulb. Cardia muscular, long, surrounded with intestinal tissue.

Teste single, outstretched, situated to left of the intestine. Precloacal supplements absent. Spicules bended, cephalated. Distal spicular end bifurcated. Gubernaculum with two dorso-caudal apophyses. Tail slender, elongate- conical, armed short setae. Caudal glands and spinneret well developed.

Type locality and habitat: Can Gio mangrove, Ho Chi Minh city, Vietnam. Shore

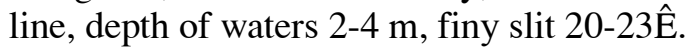

Type material: holotype male on slide number 33/III and paratypes two males and three females deposited at the nematode collection on the Institute of Inland Waters Biology, Borok, Russia. Paratypes 29 males and 18 females deposited at the nematode collection of the Institute of Ecology and Biological Resources, Vietnamese Academy of Science and Technology, Hanoi, Vietnam.

Table 4

Measurements of Terschellingia obesa sp. nov. (all measurements in $\mu \mathrm{m}$, except ratio)

\begin{tabular}{|c|c|c|c|c|c|}
\hline \multirow{3}{*}{ Characteristics } & \multirow{3}{*}{$\underset{\substack{\lambda \\
\text { Holotype }}}{ }$} & \multicolumn{4}{|c|}{ Paratypes } \\
\hline & & \multicolumn{2}{|c|}{$31 \hat{\jmath}$} & \multicolumn{2}{|c|}{$21+90$} \\
\hline & & range & mean & range & mean \\
\hline $\mathrm{L}$ & 777 & $611-945$ & 772 & $750-943$ & 875 \\
\hline $\mathrm{a}$ & 25 & $18-31$ & 25 & $16-28$ & 21 \\
\hline $\mathrm{b}$ & 4.4 & $3.9-4.6$ & 4.3 & $3.8-4.8$ & 4.3 \\
\hline $\mathrm{c}$ & 9.3 & $7.2-10.4$ & 8.8 & $7.2-10.0$ & 8.2 \\
\hline$c^{\prime}$ & 3.5 & $2.7-4.4$ & 3.6 & $2.9-5.5$ & 4.0 \\
\hline $\mathrm{V}, \%$ & --- & --- & --- & $60.5-67.7$ & 64.7 \\
\hline Labial region width & 15 & $13-18$ & 15 & $13-18$ & 16 \\
\hline Cephalic setae length & 1.5 & 1.5 & 1.5 & 1.5 & 1.5 \\
\hline Anterior body end to amphids & 4.0 & $3.0-6.0$ & 4.5 & $3.0-5.0$ & 4.0 \\
\hline Oesophagus length & 175 & $118-218$ & 179 & $179-224$ & 203 \\
\hline Posterior end of oesophagus to vulva & --- & --- & --- & $287-451$ & 363 \\
\hline Posterior end of oesophagus to cloaca & 518 & $427-644$ & 504 & --- & $\begin{array}{l}-- \\
\end{array}$ \\
\hline Vulva to anus & --- & --- & --- & $161-259$ & 201 \\
\hline Tail length & 84 & 56-101 & 89 & $87-123$ & 108 \\
\hline Spicules length (along arch) & 28 & $28-34$ & 31 & --- & --- \\
\hline
\end{tabular}

Differential diagnosis: the new species resembles to Terschellingia monohystera Wieser et Hopper, 1967 and Terschellingia brevicaudata Ott, 1972. but it differs from $T$. monohystera by the shorter cephalic setae (in T. monohystera cephalic setae $4.0 \mu \mathrm{m}$ long $v s$ cephalic setae $1.5 \mu \mathrm{m}$ long in new species), another localization of vulva (in $T$. monohystera $V=44 \%$ vs $V=60.5-67.7 \%$ in new species) and absence of basal bulb of oesophagus (Wieser et Hopper, 1967). New species differs from $T$. brevicaudata by the shorter body (in $T$. brevicaudata $L=1.40-1.61 \mathrm{~mm}$ vs $L=0.61$ -
$1.01 \mathrm{~mm}$ in new species), shorter cephalic setae (in $T$. brevicaudata cephalic setae $4.5-5.0 \mu \mathrm{m}$ long $v s$ cephalic setae $1.5 \mu \mathrm{m}$ in new species), shorter spicules (in T. brevicaudata spicules 47$53 \mu \mathrm{m}$ long $v s$ spicules $28-34 \mu \mathrm{m}$ long in new species) and presence of one ovary in females only (Ott, 1972).

Etymology: the species name means "obese".

Acknowledgement: this study was partly supported by the Project Impact of mangrove exploitation on the Benthic ecosystem and the 
assessment of tools for sustainable management (IMABE) which granted by VLIR, Belgium. The authors thank the financial assistance from VLIR IMABE Project during the period of study.

\section{REFERENCES}

1. Boucher G., Helleouët M.-N., 1977: Bull. Mus. Nath. Hist. Nat. Paris, $3^{\mathrm{e}}$ ser., № 427,
Zool., 293: 85-122.

2. Gagarin V. G., Nguyen Vu Thanh, 2006: Zoosystematica Rossica, 15(2): 215-220.

3. Ott J. A., 1972: Int. Rev. ges. Hyrobiol. Hidrogr., 57: 463-496.

4. Timm R. V., 1961: Proc. Pakist. Acad. Sci., 1: $1-88$.

5. Wieser W., Hopper., 1967: Bull. Mus. Comp. Zool. Harv., 135: 239-344.

\section{BỐN LOÀI TUYẾN TRÙNG MONHYSTERIDS MỚI (NEMATODA, MONHYSTERIDA) TỪ RỪNG NGậP MặN Ở CỬA SÔNG MÊ KÔNG, VIỆT NAM}

\section{VLADIMIR G. GAGARIN, NGUYÊ̂̃N VŨ THANH}

\section{TÓM TÁ́T}

Mô tả bốn loài loài tuyến trùng biển sống tự do thuộc bộ Monhysterida tại rừng ngập mặn ở cửa sông Mê Kông, Việt Nam.

Loài mới Thalassomonhystera tenuis sp. nov. về hình thái học tương đối giống loài Thalassomonhystera pusilla (Boucher, Heleouët, 1977) song khác biệt với loài trên bởi chiều cao đầu, vùng môi tách biệt, các lông cứng vòng ngoài cùng trên đầu tương đối dài hơn, thực quản và gai sinh dục ngắn hơn và trợ gai không có mấu và có sự hiện diện của các lông cứng trên chóp đuôi.

Loài mới Diplolaimelloides elegans sp. nov. tương đối giống với loài đã biết trong giống Diplolaimelloides meyli Timm, 1961, song khác biệt bởi đuôi dài hơn, mảnh hơn và vị trí lỗ sinh dục cái.

Loài mới Sphaerotheristus supplementatus sp. nov. tương đối giống với loài Sphaerotheristus parvus Gagarin, Nguyen Vu Thanh, 2006, song khác biệt bởi cơ thể dài, mảnh và các trợ gai dạng nhú ở con đực

Loài mới Terschellingia obesa sp. nov. tương đối giống loài Terschellingia monohystera Wieser, Hopper 1967 và loài Terschellingia brevicaudata Ott, 1972, tuy nhiên nó khác biệt so với T. monhystera ở chỗ lông cứng đầu ngắn hơn, vị trí lỗ sinh dục cái và không có diều sau thực quản. Loài mới Terschellingia obesa sp. nov. cũng khác biệt so với loài $T$. brevicaudata bởi cơ thể, lông cứng đầu và gai sinh dục ngắn hơn, ngoài ra ở tất cả các con cái còn khác biệt bởi chúng chỉ có 1 buồng trứng. 